\title{
DETERMINANTS OF VISITOR SPENDING: THE WACKY WINE FESTIVAL AS A CASE STUDY
}

\author{
Melville Saayman* \\ North-West University \\ melville.saayman@nwu.ac.za \\ Waldo Krugell\# \\ North-West University \\ waldo.krugell@nwu.ac.za
}

\begin{abstract}
The Wacky Wine Festival in Robertson, South Africa, is one of the country's largest wine festivals. The uniqueness of this wine festival is that it takes place on an existing wine route where 48 wine farms actively participate in the event. Events such as these have long been used to promote a destination or region and its products in order to generate revenue and grow tourism. This paper presents the results of a survey that was conducted during the festival in June 2009 in which 420 questionnaires were completed by visitors to the festival. The aim was to identify the determinants of visitors' spending at the festival. Factor analysis was applied to differentiate three types of wine tourists: Festinos, Epicureans and Social Adventurists. Consequently, these three groupings and other sociodemographic and behavioural attributes of festival attendees were regressed as independent variables against expenditure in an attempt to refine future marketing strategies. It was the first time that this type of research was conducted at a wine festival in South Africa, and the findings indicated that determinants of visitor spending differ from event to event. Results also showed that a variety of socio-demographic and behavioural determinants influence spending. These include age, days spent at the festival, place of origin and repeat visits. The study also identified the high spending market ("epicureans") that could assist marketers and event organisers in increasing the economic effects of the event.
\end{abstract}

\section{Keywords:}

Wine tourism, Regression analysis, Events, Robertson Wine Route, South Africa

\footnotetext{
* Prof Melville Saayman is professor in Tourism at the Potchefstroom Campus of North-West University, South Africa

\# Prof Waldo Krugell is an associate professor in the School of Economics at Potchefstroom Campus of North-West University, South Afric
} 


\section{INTRODUCTION}

Wine cultivation in South Africa was started by Jan van Riebeeck three years after arriving at the Cape of Good Hope in 1652. Van Riebeeck recommended to the Dutch East India Company that the Cape, with its suitable grape-growing climate, would serve as a useful victualling station for their ships on the passage to the East (Hoeksema, 2009). Thus, in 1655, a shipment of grapevine cuttings, mainly from France, arrived in Table Bay and soon afterwards the first vineyards were planted. On 2 February 1659, the first wine was made by Van Riebeeck himself (Southern Hemisphere, 1993). According to Preston-Whyte (2000:106), Van Riebeeck noted in his diary "Today, praise be the God, wine was made for the first time from the Cape grape". Since that experience, vineyards have been planted throughout the Western Cape and wine cultivation has expanded to other parts of the country such as the Northern Cape (Hoeksema, 2009). These developments laid the foundation for the subsequent establishment of wine tourism. From an international perspective South Africa is the sixth-largest wine producer, with France and Spain as the leading countries (Hall, Sharples, Cambourne \& Macionis, 2002). While traditional wine producers are experiencing a decline in world sales, South African exports have grown by $26 \%$ in the period 1990-2001, which is significantly higher that global sales (Anon, 2007). In this regard South Africa is seen as one of the "new world" wine producers, a category that includes countries such as Australia, the United States of America, New Zealand and Chile (Hall, et al. 2002). In 1971, the first official wine route in South Africa was developed in the Stellenbosch area. Once established, the success of the Stellenbosch Wine Route led to the development of another 15 wine routes, as wine producers beyond the Stellenbosch area began to recognise the potential benefits of wine route tourism (Preston-Whyte, 2000).

The Wacky Wine Festival at Robertson in the Western Cape Province started in 2004 with just 2 500 visitors and grew to 16000 visitors by 2008. This festival is unique in the sense that the festival takes place along the Robertson Wine Route. This route consists of 48 wine farms each producing its own wine. For the festival, each wine farm hosts its own entertainment programme, and wine tasting is offered by all wine farms and not merely at one venue or location, as is frequently the case at other wine festivals. Additional activities offered by the different wine farms include food tasting, stalls selling arts and crafts, children's activities, musical performances, bottling of the tourists' own wine, and even adventure activities such as sky diving.

Hall, et al. (2002) indicated that wine festivals are typically used to promote a wine region, to attract visitors and engage the local community and to promote the consumption of specific wine products. The aim of a wine festival is to increase the revenues of the wine producers in both the short and long term, while the spillover effects benefit the community in the area. According to Charters and Ali-Knight (2002), research on wine tourism has been expanding rapidly, but very little is known about the spending behaviour of wine tourists. Defining a wine tourist is a challenge: researchers such as Charters and Ali-Knight (2002) and Dodd and Bigotte (1997) clearly indicate that there are very different categories of wine tourists, which makes it difficult to capture the concept of a wine tourist in one definition. The categories include the wine lover, the wine connoisseur, those interested in wine, the wine novice, the curious, the drinker - to name but a few. Hence, there is no single accepted definition. For the purpose of this paper, however, a wine tourist is seen as someone who travels primarily for a wine experience and makes an economic input to the area in which he/she travels. With the increase in festivals, and especially wine festivals, in South Africa, as well as an increase in wine farms themselves, it is becoming important to examine the determinants of wine tourists' spending. 
This information has become paramount for marketing decision-making, as it can assist marketers in the use of scarce resources.

The aim of this paper is to examine the determinants of the spending of wine tourists at the Wacky Wine Festival. The paper is structured as follows: the following section presents a brief review of the literature regarding the determinants of spending of tourists at events and festivals. This is followed by the empirical analysis, which is divided into sub-sections that describe the data collected and the regression analysis of the determinants of spending. Findings and implications follow the results, and these are followed by a final section that presents some conclusions and recommendations.

\section{LITERATURE REVIEW}

Saayman, et al. (2007) argue cogently that a greater understanding of visitor expenditure patterns can help marketers and event organisers to increase the economic impact of events and tourism activities. In addition, Jang, Bai, Hong and O'Leary (2004) state that the identification of the determinants of spending is useful not only to understand expenditure patterns but also to identify market segments. Kruger (2008) defines market segmentation as a process of $(a)$ grouping existing and potential visitors with similar preferences into groups called market segments, (b) selecting the most promising segments as target markets, and (c) designing marketing mixes that satisfy the special needs, desires and behaviours of target markets. These markets can be determined by an analysis of the key segmentation bases such as socio-demographic (for example age, income, gender, occupation and language) geographic (for example country, province, city) and behavioural (for example travel motives, repeat visits). According to Kruger (2008), segmentation-based determinants of visitor expenditure is the most effective way to identify economically viable markets, in other words, the visitors that spend the most money.

To better understand visitor expenditure, Craggs and Schofield (2006) identified a range of socio-demographic and behavioural determinants that influence visitor expenditure. A number of researchers have argued in favour of the benefits of identifying the determinants of spending, including Kruger (2008), Mok and Iverson (2000), Saayman and Saayman (2006), Kastenholtz (2005), Spotts and Mahoney (1997) and Wilton and Nickerson (2006), to name but a few. The following advantages have been put forward:

- Greater understanding of spending behaviour;

- Market profiles can be identified;

- Niche marketing can be applied;

- High-yielding markets can be identified;

- Strategic marketing and planning can be done;

- Product development can take place;

- Policies can be formulated; and

- Organisers can gain a competitive advantage.

Research on socio-demographic variables and the expenditure of tourists at a range of events 
has revealed that visitors with a higher education do not necessarily spend more. In fact, it seems that they spend less per day than do less educated visitors (see Saayman, et al., 2007; Mak, et al., 1977 and Gokovali, et al., 2007). Results on the effect of marital status on expenditure are inconclusive (Saayman, et al., 2007). In an analysis of travel party or group size Mak, et al. (1977), Thrane (2002), Seiler, et al. (2002) and Lee (2001) found a positive relationship between group size and expenditure. Saayman and Saayman (2008), however, found the opposite. If one analyses the presence of children in the travel party, it seems that children have a negative impact in the sense that spending decreases (see Cai, Hang and Morrison, 1995; Saayman and Saayman, 2006, and Cannon and Ford, 2002). Lee (2001), however, found that the presence of children had no significant impact on spending. Age has been found to be inconclusive since both Thrane (2002) and Saayman and Saayman (2006) found a positive relationship between age and spending, while Pouta, et al. (2006) and Mehmetoglu (2007) found the opposite. The same applies to gender differentials: Thrane (2002) found males to be higher spenders, while Letho, et al. (2004) and Craggs and Schofield (2006) found the opposite.

Most of the travel expenditure studies confirmed that the length of stay has a positive relationship with expenditure (see Saayman, et al., 2007; Seiler, et al., 2002). However, analysis of the length of stay and expenditure per day by Mehmetoglu (2007) Sun and Stynes (2006) and Downward and Lumsdon (2004) found that there is a decrease in spending per day as the length of stay increases. The place of origin has also been found to be a determinant of spending in South African studies by Saayman and Saayman (2008) and by Slabbert, et al. (2007) as tourists and visitors from more affluent provinces (with higher disposable income) such as Gauteng and Western Cape spend more than do their counterparts from other provinces.

The distance travelled has also been found to have a positive relationship, which is to be expected as the travel cost incurred increases total spending. However, the literature indicates that even when travel cost is omitted, people from further afield still spend more as they stay longer at the destination (see Long and Purdue, 1990; Saayman, et al., 2007 and Cannon and Ford, 2002).

An analysis of travel behaviour shows that the reason for travelling has a significant impact on spending (Mok and Iverson, 2000; Letho, et al., 2004; Kruger, et al., 2009). In other words, what are the key motives for visiting the festival? Those who decide well in advance to travel also spend more than do those who decide closer to the event or time of departure (Thrane, 2002; Saayman and Saayman, 2006). This again applies to those who attend other festivals (Saayman and Saayman, 2006). First-time visitors also have a positive relationship with expenditure according to Oppermann (1997), Jang, et al. (2004) and Pouta, Neuvonen and Sievänen (2006). Confusingly, however, Gyte and Phelps (1998) and Long and Perdue (1990) found the opposite: repeat visitors spend more, they argue.

From the literature review of national and international festivals and events the following determinants have been identified (see FIGURE 1): 


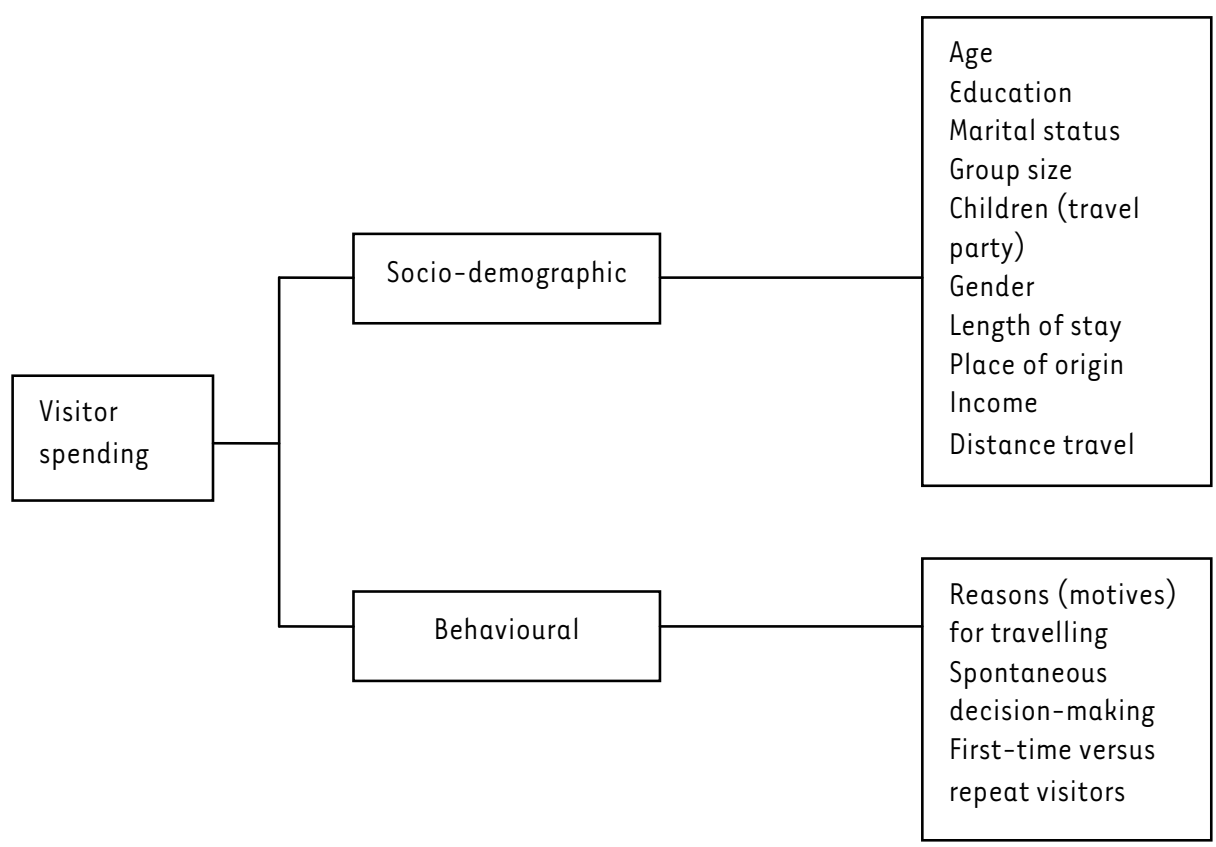

\section{FIGURE 1: Key determinants in festivals}

\section{Source: Compiled by authors}

The above figure shows that a wide range of variables influence visitor spending. Kruger, et al. (2009) conclude that spending behaviour and patterns differ from one event or attraction to the next. The following section explains the analysis of the determinants of spending from data collected at the Wacky Wine Festival.

\section{EMPIRICAL ANALYSIS}

To examine the determinants of visitor spending at the Wacky Wine Festival, a survey was conducted on 5 and 6 June 2009, by means of a structured questionnaire. The questionnaire was developed by the Institute for Tourism and Leisure Studies, and it has been successfully used in a number of other studies (see Saayman and Saayman (2006) at the Klein Karoo National Arts Festival (KKNK), and Kruger (2009) at the Aardklop National Arts Festival in South Africa.). The questionnaire is composed of demographic, behavioural and expenditure questions. As it was not possible to conduct the survey at all 48 wine farms, the survey team, in conjunction with the festival organisers, identified the farms that most people would visit during the course of the festival. Field workers were then placed at these wine farms, which included the Van Loveren, Bon Courage, Cloverfield and Graham Beck wine farms. The training of the field workers emphasised that they should avoid duplicating interviews with attendees who had been surveyed at a different venue. Four hundred and fifty questionnaires $(n=450)$ were distributed of which 420 were used in this paper. Availability sampling was used, and based on the estimated 16000 visitors, 420 is found to be sufficient (Cooper \& Emory, 1995). Visitors to the festival had to buy an access ticket, and from previous records, the forecast of 16000 visitors was seen as 
dependable. The SPSSTM statistical software package was used to analyse the data.

\subsection{Data description}

The first step in the analysis was to describe the data. Of the 420 respondents, approximately $41 \%$ were male and $59 \%$ were female. Some $60 \%$ of the respondents were Afrikaans-speaking and $38 \%$ were English-speaking. The age distribution is skewed to the right with approximately $40 \%$ of the respondents being between 19 and 30 years of age and another $23 \%$ between 31 and 40 years of age. In terms of occupation, most of the respondents were either professionals $(30 \%)$, in management $(16 \%)$ or self-employed $(13 \%)$. Another $10 \%$ were students. The other ten occupation categories captured the activities of the remaining third of the respondents. The complete table is presented in Appendix A.

Of the visitors who were interviewed, $80 \%$ indicated that the festival was the main or only reason for visiting Robertson at the time. Approximately $40 \%$ were first-time visitors to the Wacky Wine Festival, with $56 \%$ being return visitors. Of these return visitors, $34 \%$ were visiting for their second year, and for $24 \%$ it was their third festival. Approximately $12 \%$ of the people who participated in the survey were residents of Robertson and the rest were visitors. Most of the visitors were from the Western Cape, followed by those from Gauteng and those from the Eastern Cape. Many of the people who were interviewed had previously also attended other festivals. Nearly $10 \%$ had also attended the Cultivaria Festival, $25 \%$ had been to the Knysna Oyster Festival and $30 \%$ had supported the Stellenbosch Wine Festival.

The questionnaire also asked interviewees about their reasons for visiting the Wacky Wine Festival. Respondents evaluated 22 possible reasons on a five-point scale, ranging from not important at all to extremely important. The results show that the following were the most common reasons: to get away from routine, to relax and to spend time with friends. Concerning the festival itself, respondents indicated that the opportunity to taste a variety of wines, the quality of the products, value for money and the fact the festival combines wine, cheese and entertainment are extremely important. In order to indentify market segments among wine tourists and examine the segments as explanations of spending, factor analysis was applied to reduce the number of variables included in the model and to determine the relationship structure among the variables retained in the model. The systematic elimination of variables not contributing significantly to the refined data set was performed using Varimax Rotation. Variables with factor loadings $\geq 0.50$ were retained, leading to a model explaining a total of $66 \%$ of the variance. Given the previously discussed complexity associated with the broad definitions of wine tourists, variables with factor loadings greater than 0.7 were considered as major descriptors of differences among three groups of wine festival attendees. The first and predominant group, called "Festinos", accounted for $29 \%$ of the variance and centred on the generic needs of festival attendees (relax, time with friends, variety of wines, quality products, value for money, differentiation, a break in routine, uniqueness, meet new people, be sociable). The second group, called "Epicureans", explained a further $19 \%$ of the variance and related to an interest in improved knowledge and ideas regarding wine, cheese and related entertainment. The third group accounted for $18 \%$ of the variance and focused on benefits offered to friends and family, convenience and social status, and were termed "Social Adventurers". TABLE 1 shows the classification and associated motivations. 
TABLE 1: Types of festival visitors by motivation

\begin{tabular}{|c|c|c|}
\hline FESTINOS & EPICUREANS & SOCIAL ADVENTURERS \\
\hline $\begin{array}{l}\text { - To relax } \\
\text { - To spend time with friends } \\
\text { - The festival offers a } \\
\text { variety of wines } \\
\text { - The festival offers quality } \\
\text { products } \\
\text { - The festival is value of } \\
\text { money } \\
\text { - Wacky Wine is different } \\
\text { - } \quad \text { To get away from routine } \\
\text { - The festival is a unique } \\
\text { - } \quad \text { To meet new people } \\
\text { - } \quad \text { It is a sociable festival } \\
\text { - } \quad \text { t is an annual } \\
\text { commitment } \\
\text { - The festival combines } \\
\text { cheese, wine and } \\
\text { entertainment } \\
\text { An opportunity to taste } \\
\text { wine }\end{array}$ & $\begin{array}{l}\text { - The festival is a unique } \\
\text { experience } \\
\text { - } \quad \text { To increase my knowledge } \\
\text { of wine } \\
\text { - To obtain new ideas } \\
\text { regarding cheese and wine } \\
\text { - The festival combines } \\
\text { cheese, wine and } \\
\text { entertainment } \\
\text { - To explore the } \\
\text { environment } \\
\text { - To buy fresh/home-made } \\
\text { products } \\
\text { - An opportunity to taste } \\
\text { wine } \\
\text { Because I consider myself } \\
\text { to be a wine connoisseur }\end{array}$ & $\begin{array}{l}\text { - To meet new people } \\
\text { - It is an annual } \\
\text { commitment } \\
\text { - To buy fresh/home-made } \\
\text { products } \\
\text { - It is for the benefit of my } \\
\text { children } \\
\text { - It is the closest festival to } \\
\text { me } \\
\text { - Because the festival is } \\
\text { regarded as a status } \\
\text { symbol } \\
\text { Because I consider myself } \\
\text { - to be a wine connoisseur } \\
\text { To spend time with family }\end{array}$ \\
\hline
\end{tabular}

\section{Source: Compiled by authors}

Most of the respondents travelled in a group of four people, and there were only a few groups of more than ten people. On average, visitors spend two days at the festival, spending just one night in Robertson. Guesthouse or Bed and Breakfast accommodation is the most popular choice, followed by staying with family and friends, renting a house and camping. Very few respondents stayed in lodges or hotels in the area. TABLE 2 shows the descriptive statistics for the spending variables.

TABLE 2: Descriptive statistics for spending

\begin{tabular}{|c|c|c|c|c|}
\hline & Mean & $\begin{array}{l}\text { Standard } \\
\text { deviation }\end{array}$ & Skewness & Kurtosis \\
\hline Spending: Wine passport & R60.00 & & & \\
\hline $\begin{array}{l}\text { Spending: } \\
\text { Accommodation }\end{array}$ & R349.10 & 861.338 & 5.399 & 44.066 \\
\hline $\begin{array}{l}\text { Spending: Food and } \\
\text { restaurants }\end{array}$ & R364.35 & 624.618 & 3.075 & 13.068 \\
\hline
\end{tabular}




\begin{tabular}{lcccc} 
& Mean & $\begin{array}{l}\text { Standard } \\
\text { deviation }\end{array}$ & Skewness & Kurtosis \\
\hline $\begin{array}{l}\text { Spending: Shopping at } \\
\text { stalls }\end{array}$ & R141.93 & 415.250 & 7.051 & 67.005 \\
$\begin{array}{l}\text { Spending: Retail shopping } \\
\text { Spending: Transport to }\end{array}$ & R86.35 & 263.028 & 4.609 & 24.896 \\
$\begin{array}{l}\text { Wacky Wine } \\
\text { Spending: Souvenirs }\end{array}$ & R242.63 & 692.369 & 5.441 & 33.282 \\
TOTAL SPENDING & Rl 419.68 & 156.655 & 7.117 & 68.716 \\
\hline
\end{tabular}

Source: Compiled by authors

A wine passport, similar to an entry fee for attending the festival, cost R60 per passport per person. The other spending items are reported as spending per respondent who completed the questionnaire. From TABLE 2 it is clear that the main spending items are accommodation, food and restaurants and transport to the festival. On average, respondents spent approximately R350 on accommodation, R365 on food and restaurants and R240 on transport to the festival. These relatively small amounts are consistent with the observation that most visitors spend just two days and one night at the festival and they come mainly from nearby places in the Western Cape. These expenditure items are also the ones that show the greatest standard deviation. Shopping at stalls is, on average, higher and shows more variation than does retail shopping. As could be expected, all the expenditure variables are positively skewed with a long-tailed distribution.

Though this description of the data already yields some interesting facts, it does not explain the spending behaviour of the visitors to the festival. The following subsection contains the results of the estimation of a regression model of the determinants of spending.

\subsection{Determinants of spending}

This section presents the results of the estimation of a regression model of the determinants of the spending by visitors to the Wacky Wine Festival. The model is a simple linear regression of total spending on a number of quantitative and qualitative determinants of spending. This approach follows earlier work on the determinants of spending of visitors to festivals (see for example Slabbert, et al., 2007, and Saayman and Saayman, 2008). The estimating equation can be expressed as follows:

$$
Y_{i}=c+\beta X_{i}+u_{i}
$$

in which $Y_{i}$ represents the total spending by a visitor and $X_{i}$ is a vector of the determinants of spending. These explanatory variables may include quantitative variables like the number of days spent at the festival or the size of the group travelling together. It may also include qualitative variables that indicate the presence or absence of a quality or attribute that may influence total spending. Such qualitative (or dummy) variables may include gender, language, occupation or type of visitor. All other external influences or shocks such as the global recession are assumed to be constant. TABLE 3 lists the explanatory variables that were included in the model and their expected relationship with total spending.

The complete list of variables that are available to test as determinants of spending comprises: 
- Gender;

- Age;

- Home language;

- Occupation;

- Group size;

- Length of stay (days);

- Length of stay (nights);

- Home province; and

- Type of festival-goer by origin, by motivation and by frequency of visit.

Gender is a qualitative variable. In this case, male respondents are coded as 0 and females as 1. Thus, the regression coefficient will indicate how much the mean expenditure of females differs from the mean expenditure of males. A priori, it is not clear whether male or female visitors would spend more. TABLE 3 compares the means of spending and indicates that, on average, females did spend slightly more than males with a greater standard deviation. Age is a quantitative variable but, a priori, it is not clear what the relationship with spending may be. It may be speculated that older visitors have more discretionary income than do younger ones, but older visitors may also be more price-sensitive than younger visitors are. Home language is another quantitative variable. Here, Afrikaans-speakers are coded as 0 and English-speakers as 1 . The regression coefficient will indicate how much the mean expenditure of $\varepsilon$ nglish-speakers differs from the mean expenditure of Afrikaans-speakers. TABLE 3 below shows that Englishspeaking visitors to the festival did spend more than their Afrikaans-speaking counterparts, but Afrikaans-speakers' spending had a greater standard deviation around the mean. Occupation is also a qualitative variable, and serves as a proxy for disposable income. The variable is coded to compare the spending of salaried persons with that of self-employed visitors. Those who are self-employed are coded as 0 , with the rest of the occupation categories given as professionals, managers, students etc. In TABLE 3, it is clear that visitors in both the management and housewives groupings spent more than the other occupation groups compared to their grand mean of Rl 425.00 .

TABLE 3: Comparison of means of spending

\begin{tabular}{|c|c|c|c|c|c|c|c|}
\hline \multicolumn{4}{|c|}{ TOTAL SPENDING } & \multicolumn{4}{|c|}{ TOTAL SPENDING } \\
\hline & Mean & $N$ & $\begin{array}{c}\text { Std. } \\
\text { Deviation }\end{array}$ & & Mean & $N$ & $\begin{array}{c}\text { Std. } \\
\text { Deviation }\end{array}$ \\
\hline \multicolumn{4}{|c|}{ Gender } & \multicolumn{4}{|c|}{ Province of residence } \\
\hline Male & $1,394.00$ & 174 & 2318.219 & Western Cape & $1,908.57$ & 212 & 2320.591 \\
\hline Female & $1,437.85$ & 246 & 2519.421 & Gauteng & $4,428.18$ & 22 & 4483.018 \\
\hline \multicolumn{4}{|c|}{ Home language } & Eastern Cape & $2,523.85$ & 13 & 2517.087 \\
\hline Afrikaans & $1,387.70$ & 250 & 2663.557 & Free State & $3,910.00$ & 2 & 5529.575 \\
\hline English & $1,495.99$ & 157 & 2053.362 & North West & $8,030.00$ & 2 & 2786.001 \\
\hline Other & 275.71 & 7 & 351.4663 & Mpumalanga & $7,560.00$ & 2 & 2121.32 \\
\hline
\end{tabular}




\begin{tabular}{|c|c|c|c|c|c|c|c|}
\hline & Mean & $N$ & $\begin{array}{c}\text { Std. } \\
\text { Deviation }\end{array}$ & & Mean & $N$ & $\begin{array}{c}\text { Std. } \\
\text { Deviation }\end{array}$ \\
\hline & Occupation & & & Northern Cape & 865.00 & 2 & 982.8784 \\
\hline Professional & $1,105.56$ & 126 & 1970.808 & Limpopo & $4,410.00$ & 3 & 2996.248 \\
\hline Management & $2,023.77$ & 69 & 3554.833 & Outside RSA & $1,216.67$ & 6 & 1134.313 \\
\hline Self-employed & $1,971.25$ & 56 & 3041.817 & \multicolumn{4}{|c|}{ Type of visitor by reason for visit } \\
\hline Technical & $1,246.00$ & 10 & 1300.839 & Festinos & $1,576.05$ & 110 & 2518.734 \\
\hline Farmer & 984.21 & 19 & 1958.251 & $\begin{array}{l}\text { Social } \\
\text { adventurers }\end{array}$ & $1,204.14$ & 107 & 2256.634 \\
\hline Sales & $1,176.67$ & 12 & 1547.757 & Epicureans & $1,661.85$ & 81 & 2985.27 \\
\hline Mining & $2,488.00$ & 1 & $3.5 \varepsilon+308$ & \multicolumn{4}{|c|}{ Type of festival-goer by frequency of visit } \\
\hline Administrative & 684.17 & 12 & 984.0312 & First-timers & $1,252.19$ & 166 & 2297.419 \\
\hline Civil service & 756.67 & 3 & 1133.593 & Repeat visitors & $1,561.18$ & 234 & 2552.02 \\
\hline Education & $1,038.33$ & 12 & 1167.093 & \multicolumn{4}{|c|}{ Type of festival-goer local vs. visitors } \\
\hline Housewife & $2,518.18$ & 22 & 2594.765 & Local & $1,082.13$ & 53 & 1549.758 \\
\hline Pensioner & $1,448.42$ & 19 & 1962.539 & Visitor & $1,468.43$ & 367 & 2535.676 \\
\hline Student & 584.83 & 41 & 1289.39 & & & & \\
\hline Unemployed & $1,610.00$ & 3 & 1394.31 & & & & \\
\hline Other & $1,896.67$ & 12 & 2704.61 & & & & \\
\hline
\end{tabular}

Source: Compiled by authors

Group size and the length of stay in days and nights are qualitative variables. In each case, a positive relationship with total spending is expected. The variable indicating the home province serves as a proxy for distance and transport cost. Those who travel further to attend the festival are more likely to stay longer and to spend more on accommodation and food. TABLE 3 shows that visitors from Gauteng and the Eastern Cape on average spent more than did those from the Western Cape. In the case of the other provinces, there are too few observations for reliable inference. This is a qualitative variable and in the analysis visitors to the festival who come from the Western Cape are coded as 0 and compared to all the others. Thus, the regression coefficient will indicate how much the mean expenditure of visitors from outside the province differs from the mean expenditure of those from the Western Cape.

Finally, it is possible to distinguish between different types of visitors in terms of their origin, motivation and frequency of visit. Type-by-origin distinguishes between local Robertson residents $(=0)$ and visitors $(=1)$. Here, the visitors are, on average, expected to spend more, and this is borne out in TABLE 3. Type-by-motivation distinguishes between the groups identified by factor analysis above: Festinos, Epicureans and Social Adventurers. In the regression analysis, the Epicureans and the Social Adventurers are each compared to the Festinos. TABLE 3 shows that on average the Epicureans had the highest spending closely followed by the Festinos. The type of festival-goer by frequency of visit distinguishes between first-time visitors $(=0)$ and repeat visitors to the festival $(=1)$. Here, TABLE 3 shows that the repeat visitors, on average, spend more than do first-time visitors.

The estimation strategy involves estimating a log-linear model using the cross-section data obtained in the survey. The quantitative variables are logged, because this compresses the 
scales in which the variables are measured and allows the coefficients to be interpreted as partial elasticity coefficients. An ordinary least squares (OLS) estimator is used. The results of four specifications are reported. In the aggregate model all the responses were used and two dummy variables were used to distinguish between types of visitors by motivation. Following that, separate regressions were estimated for each of the groups. TABLE 4 presents the estimated coefficients with standard errors in brackets.

The adjusted $R^{2}$ of 0.55 indicates that the aggregate model explains $55 \%$ of the variance in total spending. The determinants of spending are found to be jointly significant. A number of the individual regression coefficients are significant at the $5 \%$ and $10 \%$ levels. TABLE 4 shows that the age of the respondent is positively and significantly related to total spending. Older visitors spend more than the younger ones. The size of the groups that visitors travel in is positively related to spending, but the coefficient is small and not significant. TABLE 4 shows that the number of days spent at the festival is an important determinant of total spending. The number of nights that visitors stay over in Robertson is also positively associated with spending, but this too is not significant. Both the gender and language variables are insignificant. The coefficients of these categorical variables indicate the relative difference between a group and its baseline category. In this case, spending is negatively associated with being female, and positively associated with being English-speaking. The differences are, however, insignificant. When the difference between local residents and visitors is considered, the difference is both positive and significant. Being a visitor is clearly associated with higher spending. In the case of first-time compared to repeat visitors, the coefficient is negative, indicating that first-time visitors tend to spend more. The difference is, however, not significant.

TABLE 4: Regression results

\begin{tabular}{lrrrr}
\hline & $\begin{array}{c}\text { Aggregate } \\
\text { Model }\end{array}$ & $\begin{array}{c}\text { Festino } \\
\text { Model }\end{array}$ & $\begin{array}{c}\text { Epicurean } \\
\text { Model }\end{array}$ & $\begin{array}{c}\text { Social } \\
\text { Adventurers } \\
\text { Model }\end{array}$ \\
\hline (Constant) & 2.080 & 1.315 & 4.214 & 3.259 \\
Age of the respondent & $(1.237)$ & $(2.170)$ & $(2.680)$ & $(4.579)$ \\
Group size & 1.078 & 1.445 & 0.659 & -0.683 \\
Days spent at the festival & $(0.318)$ & $(0.593) \star \star$ & $(0.808)$ & $(1.257)$ \\
Nights stayed in Robertson & 0.108 & -0.022 & 0.122 & 0.939 \\
Male vs. female & $(0.111)$ & $(0.204)$ & $(0.243)$ & $(0.413) \star \star$ \\
Afrikaans vs. English & 1.210 & 1.473 & 1.079 & 3.976 \\
& $(0.383) \star \star$ & $(0.565) \star \star$ & $(1.238)$ & $(1.897) \star$ \\
Locals vs. visitors & 0.049 & -0.166 & -0.233 & -1.703 \\
& $(0.301)$ & $(0.655)$ & $(0.851)$ & $(1.050)$ \\
& -0.127 & -0.273 & 0.026 & -0.134 \\
& $(0.168)$ & $(0.293)$ & $(0.331)$ & $(0.453)$ \\
& 0.031 & -0.099 & -0.470 & 0.247 \\
& $(0.190)$ & $(0.315)$ & $(0.621)$ & $(0.588)$ \\
& 0.554 & 0.328 & 0.578 & 1.168 \\
& $(0.215) \star \star$ & $(0.347)$ & $(0.618)$ & $(0.704) \star \star$
\end{tabular}




\begin{tabular}{|c|c|c|c|c|}
\hline & $\begin{array}{c}\text { Aggregate } \\
\text { Model }\end{array}$ & $\begin{array}{c}\text { Festino } \\
\text { Model }\end{array}$ & $\begin{array}{c}\text { Epicurean } \\
\text { Model }\end{array}$ & $\begin{array}{c}\text { Social } \\
\text { Adventurers } \\
\text { Model }\end{array}$ \\
\hline \multirow[t]{2}{*}{ First-timers vs. repeat visitors } & -0.263 & 0.145 & -0.531 & -0.014 \\
\hline & $(0.167)$ & $(0.336)$ & $(0.396)$ & $(0.516)$ \\
\hline \multirow[t]{2}{*}{ Festinos vs. Epicureans } & -0.158 & & & \\
\hline & $(0.189)$ & & & \\
\hline \multirow[t]{2}{*}{ Festinos vs. Social Adventurers } & -0.100 & & & \\
\hline & $(0.206)$ & & & \\
\hline \multirow[t]{2}{*}{ Self-employed vs. professional } & -0.254 & -0.504 & -0.897 & -0.125 \\
\hline & $(0.258)$ & $(0.493)$ & $(0.643)$ & $(1.047)$ \\
\hline \multirow[t]{2}{*}{ Self-employed vs. managers } & -0.135 & -0.549 & 0.038 & 0.430 \\
\hline & $(0.255)$ & $(0.519)$ & $(0.438)$ & $(0.765)$ \\
\hline \multirow[t]{2}{*}{ Self-employed vs. technical } & -0.140 & -0.987 & 0.244 & 0.871 \\
\hline & $(0.400)$ & $(0.919)$ & $(0.653)$ & (1.122) \\
\hline \multirow[t]{2}{*}{ Self-employed vs. sales } & -0.288 & -0.558 & & \\
\hline & $(0.435) \star$ & $(0.579)$ & & \\
\hline \multirow[t]{2}{*}{ Self-employed vs. farmer } & -1.120 & -1.528 & & -1.647 \\
\hline & $(0.615)$ & $(1.090)$ & & $(1.450)$ \\
\hline \multirow[t]{2}{*}{ Self-employed vs. administrative } & -0.542 & -0.858 & -0.712 & \\
\hline & $(0.609)$ & $(1.017)$ & $(1.069)$ & \\
\hline \multirow[t]{2}{*}{ Self-employed vs. civil service } & -1.741 & & & -2.165 \\
\hline & $(0.880) \star$ & & & $(1.921)$ \\
\hline \multirow[t]{2}{*}{ Self-employed vs. education } & -0.080 & -0.297 & & 1.709 \\
\hline & $(0.460)$ & $(0.668)$ & & $(1.551)$ \\
\hline \multirow[t]{2}{*}{ Self-employed vs. housewife } & 0.417 & -0.130 & -0.155 & 0.780 \\
\hline & $(0.375)$ & $(0.713)$ & $(0.931)$ & $(1.014)$ \\
\hline \multirow[t]{2}{*}{ Self-employed vs. pensioner } & -0.597 & & & 2.512 \\
\hline & $(1.183)$ & & & $(1.234) \star$ \\
\hline \multirow[t]{2}{*}{ Self-employed vs. student } & -0.948 & -1.478 & -2.223 & 0.068 \\
\hline & $(0.369) \star \star$ & $(0.706) \star \star$ & $(1.391)$ & $(1.170)$ \\
\hline \multirow[t]{2}{*}{ Self-employed vs. unemployed } & -0.737 & -1.484 & & \\
\hline & $(0.833)$ & $(1.026)$ & & \\
\hline \multirow[t]{2}{*}{ Self-employed vs. other } & 0.160 & 0.360 & & -0.007 \\
\hline & $(0.491)$ & $(0.788)$ & & $(1.251)$ \\
\hline \multirow[t]{2}{*}{ Western Cape vs. Gauteng } & 1.099 & 1.186 & 0.676 & 1.439 \\
\hline & $(0.316) \star \star$ & $(0.562) \star \star$ & $(0.751)$ & $(1.227)$ \\
\hline \multirow[t]{2}{*}{ Western Cape vs. Eastern Cape } & 0.632 & & & \\
\hline & $(0.351) \star$ & & & \\
\hline
\end{tabular}




\begin{tabular}{|c|c|c|c|c|}
\hline & $\begin{array}{c}\text { Aggregate } \\
\text { Model }\end{array}$ & $\begin{array}{l}\text { Festino } \\
\text { Model }\end{array}$ & $\begin{array}{c}\text { Epicurean } \\
\text { Model }\end{array}$ & $\begin{array}{c}\text { Social } \\
\text { Adventurers } \\
\text { Model }\end{array}$ \\
\hline Western Cape vs. Free State & $\begin{array}{r}1.513 \\
(1.383)\end{array}$ & & & \\
\hline Western Cape vs. North West & $\begin{array}{r}1.565 \\
(0.594) \star \star\end{array}$ & & $\begin{array}{r}2.253 \\
(1.032) \star \star\end{array}$ & $\begin{array}{r}2.050 \\
(1.226)\end{array}$ \\
\hline Western Cape vs. Mpumalanga & $\begin{array}{r}0.972 \\
(0.611)\end{array}$ & $\begin{array}{r}1.629 \\
(0.798) \star\end{array}$ & & \\
\hline Western Cape vs. Northern Cape & $\begin{array}{l}-0.005 \\
(0.841)\end{array}$ & $\begin{array}{l}-0.237 \\
(0.991)\end{array}$ & & $\begin{array}{l}-0.551 \\
(1.512)\end{array}$ \\
\hline Western Cape vs. Limpopo & $\begin{array}{r}0.259 \\
(0.845)\end{array}$ & & $\begin{array}{r}0.673 \\
(1.031)\end{array}$ & \\
\hline Western Cape vs. Outside RSA & $\begin{array}{l}-0.328 \\
(0.496)\end{array}$ & $\begin{array}{r}0.699 \\
(0.430)\end{array}$ & $\begin{array}{r}0.454 \\
(1.168)\end{array}$ & \\
\hline Adjusted $R^{2}$ & 0.55 & 0.47 & 0.54 & 0.45 \\
\hline
\end{tabular}

$\star \star$ Significant at a $95 \%$ confidence level

* Significant at a $90 \%$ confidence level

\section{Source: Compiled by authors}

TABLE 4 also shows the results for the type of visitor as a determinant of total spending. The coefficients are negative, which means that when compared to the Festinos, the Epicureans and Social Adventurers tend to spend less, even if the difference is not statistically significant. In the cases of occupation and province of residence, only a few of the comparisons are significant. Compared to those that are self-employed, visitors who work in sales, are civil servants or students spend significantly less. A comparison of visitors from outside the Western Cape with those who live in the Cape shows that the visitors from Gauteng, the Eastern Cape and the North West spend significantly more. As noted above, the limited number of observations for most of the provinces limits the inferences that are possible.

The different models for the different types of visitors have results that are broadly similar to those of the aggregate model. There are however a number of interesting differences to take account of. In the case of the Festinos, smaller groups are associated with higher spending and the first-time visitors tend to spend more than returning Festinos. Among the Epicureans females tend to spend more, which is the opposite of the Festinos and Social Adventurers, where the men, on average, spend more. In the cases of both the Festinos and the Epicureans, Afrikaans visitors spent more on average than English-speaking visitors. Among the Social Adventurers, age is negatively associated with spending.

\section{FINDINGS AND IMPLICATIONS}

Findings from the results clearly support Craggs and Schofield (2006), as well as Saayman and Saayman (2006), in that a range of socio-demographic and behavioural determinants influence 
visitor spending. Age was identified to be a determinant, and this result supports research completed by Thrane (2002) and Saayman and Saayman (2006), but contradicts findings by Pouta, et al. (2006) and Mehmetoglu (2007). Days spent at the festival was also identified as a determinant, thereby supporting research by Seiler, et al. (2002) and Saayman, et al. (2007), but contradicting Sun and Stynes (2006), Mehmetoglu (2007) and Downward and Lumsdon (2004).

This research also confirms place of origin as a determinant, thereby affirming research by Slabbert, et al. (2007) and Saayman and Saayman (2008). In an analysis of the travel behaviour of visitors, results show that the Epicureans followed closely by the Festinos are the high spenders. First-timers also spend less than do repeat visitors, which support research by Gyte and Phelps (1989) and Long and Purdue (1990) and contradict Oppermann (1997), Jang, et al. (2004) and Pouta, Newman and Sievänen (2006), who found the opposite.

Based on the above, the research has a number of implications.

- Firstly, marketing should be conducted in provinces such as Gauteng, North West and Eastern Cape if the intention is to attract high-spending visitors/tourists or markets with sufficient numbers of respondents. Results also indicated that respondents from the Free State Province spent more than visitors from the Eastern Cape. However, market segments are dependent on viable numbers and since there were only two Free State respondents who completed the questionnaire, a major marketing campaign is not justified. This does not mean that the Free State could not become a market in future but that before such a decision is taken more research on this particular market is required.

- Secondly, the festival programme should make provision for specialist interest groups, since the travel motives clearly showed distinctions between three different markets or groups. Perhaps compiling Wine-and-Foodie package deals for the Epicureans with a cooking course or celebrity chef, for two days and nights, with transport, for visitors from Gauteng might be a strategy worth considering?

- Thirdly, visitors older than 30 years of age should be considered as the primary market, with the younger visitors as a secondary market.

- Fourthly, the event organisers as well as the individual wine farm managers should ensure and emphasise good quality service (management of the event) and wines in order to encourage repeat visitors, especially the Festinos and Epicureans. In this regard, a loyalty system should be considered.

- Lastly, greater cooperation and relationship with other attractions and tourism products in the area must become a priority in order to offer visitors further reasons to extend their length of stay.

\section{CONCLUSIONS}

The aim of this paper was to identify the determinants of the spending of wine tourists at the Wacky Wine Festival. This was done to enable the organisers to use their resources to more accurately target markets, which will contribute to the future growth of the festival and to the economic well-being of the area. The results of the regression analysis indicated that there are a 
number of significant determinants of spending that will assist organisers in growing this event. This is the first time that this type of research has been conducted at a wine festival in South Africa, despite the country being internationally renowned for its wine and wine routes. Results from this research confirm that determinants of visitor spending differ from one event to the next. Findings indicated clear similarities with, as well as contradictions of, previous research, as indicated in the section above. The one aspect that differs from similar research is the travel motives and particularly the identification of the Epicurean market.

From this research, it is recommended that research at other wine festivals should be conducted in order to assist the growth of wine tourism by offering comparable findings. It would also be important to expand the research to determine the travel motives of visitors to other festivals, as well as the effectiveness of the branding of these routes.

\section{Acknowledgement}

The authors would like to thank the National Research Foundation for funding this research as well as the referees for their contribution in improving the article.

\section{REFERENCES}

Anon. (2007). The Wine Industry Transformation Charter. Stellenbosch: South African Wine Industry Council.

Cannon, T.F. \& Ford, J. (2002). Relationship of demographic and trip characteristics to visitor spending: an analysis of sport travel visitors across time. Tourism Economics, 8(3), pp. 263-271.

Charters, S. \& Ali-Knight, J. (2002). Who is the wine tourist? Tourism Management, 23(3), pp. 311-319.

Cai, L.A., Hong, G. \& Morrison, A.M. (1995). Household expenditure patterns for tourism products and services. Journal of Travel and Tourism Marketing, 4(4), pp. 15-40.

Cooper, D.R. \& Emory, C.W. (1995). Research Methods. Illinois: Richard D. Irwin, Inc.

Craggs, R. \& Schofield, P. (2006). Expenditure Segmentation and Visitor Profiling: Regenerating the Quays in Salford, UK. Salford: University of Salford.

Dodd, T. \& Bigotte, V. (1997). Perceptual differences among visitor groups to wineries. Journal of Travel Research, 35(3), pp. 46-51.

Downward, P. \& Lumsdon, L. (2004). Tourism transport and visitor spending: A study in the North York Moors National Park, UK. Journal of Travel Research, 42(4), pp. 415-420.

Gokovali, U.; Baher, 0.\& Kozak, M. (2007). Determinants in length of stay: A practical use of survival analysis. Tourism Management, 28(3), pp. 736-746.

Gyte, D. \& Phelps, A. (1998). Patterns of Destination Repeat Business: British tourists in Mallorca, Spain. Journal of Travel Research, 28(1), pp. 24-28.

Hall, C.M.; Sharples, L.; Cambourne, B. \& Macionis, N. (2002). Wine Tourism Around the WorldDevelopment, Management and Markets. London: Butterworth-Heinemann.

Hoeksema, H. (2009). A marketing strategy for the Northern Free State wine route. Unpublished MA Dissertation. Potchefstroom: North-West University. 
Jang, S., Bai, B., Hong, G.S. \& O'Leary, J.T. (2004). Understanding travel expenditure patterns: A study of Japanese pleasure travellers to the United States by income level. Tourism Management, 25(3), pp. 331-341.

Kruger, M. (2008). Spending behaviour of visitors to the Klein Karoo National Arts Festival. Unpublished MA Dissertation. Potchefstroom: North-West University.

Kruger, M., Saayman, M. \& Ellis, S. (2009). Determinants of visitor expenditure at the Aardklop National Arts Festival. Event Management. (In process of review).

Kastenholz, દ. (2005). Analysing determinants of visitor spending for the rural tourist market in North Portugal. Tourism Economics, 11 (4), pp. 555-569.

Lee, H. (2001). Determinants of recreational boater expenditure on trips. Tourism Management, 22(6), pp. 59-667.

Letho, X.Y.; Cai, L.A., O'Leary, J.T. \& Huan, T. (2004). Tourist shopping preferences and expenditure behaviours: The case of the Taiwanese outbound market. Journal of Vacation Marketing, 10(4), pp. 320-332.

Long, P.T. \& Purdue, R.R. (1990). The economic impact of rural festivals and special events: Assessing the spatial distribution of expenditures. Journal of Travel Research. 28(4), pp. 10-14.

Mak, J.; Monour, J. \& Yonamine, D. (1977). Determinants of visitor expenditures and visitor lengths of stay: a cross-section analysis of U.S. visitors to Hawaii. Journal of Travel Research, 15(3), pp. 5-8.

MehmetogIU, M. (2007). Nature-based tourists: The relationship between their trip expenditures and activities. Journal of Sustainable Tourism, 15(2), pp. 200-215

Mok, C. \& Iverson, T.J. (2000). Expenditure-Based segmentation: Taiwanese tourists to Guam. Tourism Management, 21(3), pp. 299-305.

Oppermann, M. (1997). Visitation of tourism attractions and tourist expenditure patterns: Repeat versus first-time visitors. Asia Pacific Journal of Tourism Research, 1(1), pp. 61-68.

Oppermann, M. (1997). First-time and repeat visitors to New Zealand. Tourism Management, 18(3), pp. 177-181.

Pouta, દ., Neuvonen, M. \& Sievänen, T. (2006). Determinants of nature trip expenditures in Southern Finland - Implications for nature tourism development. Scandinavian Journal of Hospitality and Tourism, 6(2), pp. 118-135.

Preston-Whyte, R. (2000). Wine routes in South Africa. In: Hall, C.M., Sharples, L., Cambourne, B. \& Macionis, N. (eds.), Wine tourism around the world. London: Butterworth-Heinemann. (pp. 102-114)

Slabbert, E., Saayman, M., Saayman, A. \& Viviers, P. (2008). Die sosio-ekonomiese impak van besoekers aan die ABSA KKNK. Potchefstroom: Instituut vir Toerisme en Vryetydstudies.

Spotts, D, M. \& Mahoney, E.M. (1991). Segmenting visitors to a destinations region based on the volume of their expenditure. Journal of Travel Research, 29(4), pp. 24-31.

Sun, Y. \& Stynes, D.J. (2006). A note on estimating visitor spending per day/nights basis. Tourism Management, 27(4), pp. 721-725.

Saayman, A. \& Saayman, M. (2006). The Socio-demographics and visitation patterns of arts festivals in South Africa. Events Management, 9(4), pp. 211-222.

Saayman, M. \& Saayman, A. (2008). Socio-demographic and behavioural determinants of visitor spending at a national arts festival: a panel data analysis. World Journal on Events, 1(1), pp. 28-33. 
SaaymaN, M., Krugell, W. \& Van der Merwe, P. (2007). The determinants of spending by biltong hunters. South African Journal of Economics and Management Sciences, 10(2), pp. 184-194.

Seiler, V.L.; Seiler, M.J.; Hsieh, C. \& Hsieh, S. (2002). Modelling travel expenditures for Taiwanese tourism. Journal of Travel and Tourism Marketing, 14(4), pp. 47-59.

Southern Hemisphere. (1993). Available from: http://www.southernwines.com/about.cfm. (Accessed 19 March 2008)

Thrane, C. (2002). Jazz festival visitors and their expenditures: linking spending patterns to music interest. Journal of Travel Research, 40(3), pp. 281-286.

Wilton, J.J, \& Nickerson, N.P. (2006). Collecting and using visitor spending data. Journal of Travel Research, 45(1), pp. 17-25. 
Saayman \& Krugell

\section{Appendix A: Descriptive Statistics}

TABLE Al: Occupation

\begin{tabular}{|c|c|c|c|c|c|}
\hline & & Frequency & Percent & Valid Percent & $\begin{array}{c}\text { Cumulative } \\
\text { Percent }\end{array}$ \\
\hline \multirow[t]{16}{*}{ Valid } & Professional & 128 & 30.2 & 30.4 & 30.4 \\
\hline & Management & 69 & 16.3 & 16.4 & 46.8 \\
\hline & Self-employed & 56 & 13.2 & 13.3 & 60.1 \\
\hline & Technical & 10 & 2.4 & 2.4 & 62.5 \\
\hline & Sales & 12 & 2.8 & 2.9 & 65.3 \\
\hline & Farmer & 20 & 4.7 & 4.8 & 70.1 \\
\hline & Mining & 1 & .2 & .2 & 70.3 \\
\hline & Administrative & 12 & 2.8 & 2.9 & 73.2 \\
\hline & Civil service & 3 & .7 & .7 & 73.9 \\
\hline & Education & 12 & 2.8 & 2.9 & 76.7 \\
\hline & Housewife & 22 & 5.2 & 5.2 & 81.9 \\
\hline & Pensioner & 19 & 4.5 & 4.5 & 86.5 \\
\hline & Student & 41 & 9.7 & 9.7 & 96.2 \\
\hline & Unemployed & 4 & .9 & 1.0 & 97.1 \\
\hline & Other & 12 & 2.8 & 2.9 & 100.0 \\
\hline & Total & 421 & 99.3 & 100.0 & \\
\hline Missing & 0 & 3 & .7 & & \\
\hline Total & & 424 & 100.0 & & \\
\hline
\end{tabular}

Source: Compiled by authors 